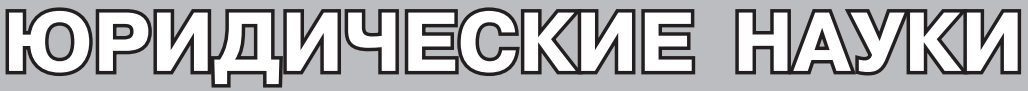

\section{Проблемы правового восприятия явцений экстремизма и терроризма в разных ментальных цивимизациях: общетеоретический и историко-фимософские аспекты}

\author{
C. С. ОГАНЕСЯН \\ Научно-исследовательский институт ФСИН России, г. Москва, Российская \\ Федерация \\ ORCID: https://orcid.org/0000-0002-7257-7760, e-mail: ossduma@mail.ru
}

\section{Т. А. ХААДИ}

Институт стратегии развития образования Российской академии образования, г. Москва, Российская Федерация

ORCID: https://orcid.org/0000-0003-3695-452X, e-mail: tarim.khadi@mail.ru

Р е фер ат

Введение: в статье раскрываются специфика восприятия таких явлений, как экстремизм и терроризм, в разных ментальных цивилизациях - язычества (многобожия), единобожия и научного мировосприятия - с позиций правового сознания этносов: обычного, канонического и светского. Цель: показать, что те явления, которые в современном мире именуются экстремизмом и терроризмом и подлежат уголовному наказанию, в ментальные эпохи язычества и монотеизма воспринимались прямо противоположным образом. Методы исследования: использованы методы анализа исторических сведений о явлениях экстремизма и терроризма в разные эпохи, связанные с цивилизационной ментальностью этносов и народов, а также обобщение (синтез) полученных сведений. Результаты исследования: демонстрация отношения к тем явлениям, которые сегодня именуются экстремизмом и терроризмом, в разных ментальных цивилизациях позволяет не только понять исторически обусловленную природу названных явлений, но и выстроить адекватную систему противодействия им посредством изменения существующих в настоящее время подходов и методов. Выводы: современные религиозные экстремисты и террористы являются выразителями уходящих с исторической арены религиозного мировосприятия и соответствующего образа жизни. Их ресоциализацию необходимо проводить с учетом цивилизационной ментальности именно религиозных людей, опираясь прежде всего на толерантные возможности самих священных писаний. В ближайшие годы на фоне закономерного угасания религиозного экстремизма и терроризма произойдет усиление таких видов светского экстремизма и терроризма, как политический, социальный, расовый и языковой, то есть всех тех, которые перечислены в ст. 280 и 282 УК РФ. Данные виды экстремизма требуют прежде всего формирования высокого правосознания граждан страны, и здесь без системной и целенаправленной работы воспитательных и психологических служб УИС не обойтись.

К л юче в ы е с ло в а : экстремизм; терроризм; монотеизм; язычество; научное мировосприятие; религиозные войны. 
12.00.01 - Теория и история права и государства; история учений о праве и государстве.

Д ля ц и ти р о в а н и я : Оганесян С. С., Хаади Т. А. Проблемы правового восприятия явлений экстремизма и терроризма в разных ментальных цивилизациях: общетеоретический и историко-философские аспекты. Пенитенциарная наука, 2021, т. 15, № 2 (54), с. 237-246. DOI 10.46741/2686-9764-2021-15-2-237-246.

\title{
Features of Legal Perception of the Phenomena of Extremism and Terrorism in Different Mental Civilizations: General Theoretical and Historical- Philosophical Aspects
}

\author{
SERGEI S. OGANESYAN \\ Research Institute of FSIN Russia, Moscow, Russian Federation \\ ORCID: orcid.org/0000-0002-7257-7760,e-mail: ossduma@mail.ru
}

TARIM A. KHAADI

Institute for Strategy of Education Development of the Russian Academy of Education, Moscow, Russian Federation

ORCID: https://orcid.org/0000-0003-3695-452X, e-mail: tarim.khadi@mail.ru

\begin{abstract}
Introduction: the article reveals how extremism and terrorism are perceived in different mental civilizations: paganism (polytheism), monotheism and scientific worldview, from the standpoint of the legal consciousness of ordinary, canonical and secularethnic groups. The aim is to show that those phenomena which in the modern world are called extremism and terrorism and are subject to criminal punishment were perceived in exactly the opposite way in the mental eras of paganism and monotheism. Research methods: we use analysis of historical information about the phenomena of extremism and terrorism in different eras, related to the civilizational mentality of ethnic groups and peoples; we also use generalization (synthesis) of the information obtained. Results: revealing the attitude toward the phenomena that are now called "extremism" and "terrorism" in different mental civilizations allows us not only to understand the historically determined nature of these phenomena, but also to build an adequate system to counter them by changing existing approaches and methods. Conclusions: modern religious extremists and terrorists representinterests of the religious worldview and the way of life that are leaving the historical arena. Their re-socialization should be carried out taking into account civilizational mentality of religious people, relying primarily on the tolerant capabilities of the Holy Scriptures themselves. In the coming years, against the background of the natural decline of religious extremism and terrorism, there will be a rise of such types of "secular" extremism and terrorism as political, social, racial and linguistic, i.e. all those types of extremism that are listed in Articles 280 and 282 of the Criminal Code of the Russian Federation. In order to counteract these types of extremism, it is necessary, first of all, to develop high legal awareness in citizens; in this regard, it is crucial that educational and psychological services of the Russian Penal System carry out system-wide and purposeful work in this direction.
\end{abstract}

Keywords: extremism; terrorism; monotheism; paganism; scientific worldview; religious wars.

12.00.01 - Theory and history of law and state; history of law and state.

For citation: Oganesyan S.S., Khaadi T.A. Features of legal perception of the phenomena of extremism and terrorism in different mental civilizations: general theoretical and historical-philosophical aspects. Penitentiary Science, 2021, vol. 15, no. 2 (54), pp. 237-246. DOI 10.46741/2686-9764-2021-15-2-237-246. 


\section{Введение}

В настоящее время в мире существует немало проблем, связанных с профилактикой экстремизма и терроризма и противодействием этим крайне деструктивным для современного мира явлениям, несущим прямую угрозу безопасности как отдельных государств, так и всего мирового содружества наций.

Цель, поставленная в данной статье, состоит в том, чтобы показать особенности восприятия экстремизма и терроризма в разных ментальных цивилизациях. Отсюда в числе важнейших задач - ретроспективное рассмотрение явлений экстремизма и терроризма, воспринимаемых сознанием подавляющего большинства современных людей в качестве крайне негативных явлений, подлежащих уголовному преследованию, в другие ментальные эпохи.

Заявленная тема представляется, вне всякого сомнения, актуальной, прежде всего потому, что демонстрация отношения к тем явлениям, которые сегодня именуются экстремизмом и терроризмом, в разных ментальных цивилизациях позволяет не только понять их исторически обусловленную природу, но и выстроить адекватную систему противодействия им в современном мире, в частности изменить существующие подходы к ресоциализации лиц, осужденных за религиозный экстремизм и терроризм, в условиях мест лишения свободы.

Теоретическую основу исследования образует ранее изложенная нами во многих публикациях точка зрения о том, что основная масса человечества в своем историческом развитии последовательно переходила от ментальности язычества (многобожия) к мировосприятию, основанному на единобожии, а от него - к научному восприятию мира с соответствующими правовыми системами [8; 9].

Bсе нормы поведения (законодательные системы) в первых двух ментальных цивилизациях, которые являлись религиозными, предопределялись мировосприятием, а также правилами, которые были даны людям, по их глубокому убеждению, извне (внешними силами) и отчуждены от их самостоятельной интеллектуальной деятельности.

Язычниками нормы и правила, которым они безоговорочно подчинялись, воспринимались как завещанные предками, которые после земной смерти становились богами и из потустороннего мира сообщали своим потомкам, как им надлежит жить, чтобы избежать страданий и бед, а при монотеизме в качестве обязательных для исполнения норм и правил (законодательных систем), ниспосланных через пророков Единым Богом.

Причем важно отметить, что этносы и народы (племена), как показывает процесс развития человечества, переходили от одной ментальной стадии к другой не одномоментно и не разом, а в разное историческое время по мере созревания (ментального и социально-экономического), и переход этот нередко затягивался на столетия [8; 9].

Самым продолжительным был и остается этап пребывания человеческих сообществ (семей, родов и племен) в ментальной стадии язычества со всеми его течениями и направлениями (анимизм, фетишизм, шаманизм и др.). Даже в наши дни в затерянных уголках планеты обнаруживаются племена, обладающие именно таким мировосприятием.

С точки зрения правовых отношений этап пребывания этносов и народов в язычестве, как известно, определяется как период, связанный с действием обычного права, то есть права, предопределяемого обычаями и традициями, действовавшими в семье, роде и племени. При этом все без исключения нормы и правила в них строго были детерминированы сугубо языческими религиозными воззрениями [8; 9].

Следующий этап - монотеизм (единобожие). Первым человеческим сообществом (народом), который стал жить с опорой на мировоззренческие основы единобожия, как известно, был народ Израиля, образовавшийся от двенадцати сынов (колен) Якова. Именно он впервые в истории человечества стал руководствоваться мировосприятием, а также нормами и правилами единобожия, которые были переданы ему через пророка Моисея [8; 9].

Здесь мы не упустим случая высказаться по поводу бытующего в философии марксизма афоризма «Общественное бытие [людей] определяет их сознание» [7]

Дело в том, что народу Израиля сведения о новом мировосприятии, а также о нормах и правилах их должного бытия были сообщены задолго до того, как они приобрели возможность иметь это бытие на тех землях, в которые привел их Единый Бог, то есть не бытие определило их сознание, когда они 
создали свое государство после сорока лет пребывания в пустыне, а новое сознание, согласно Торе данное извне Единым Богом, внедрялось на протяжении нескольких десятилетий и стало для людей основой организации жизни по новым нормам и правилам [12].

Впрочем, подобное ниспослание новых принципов организации жизни, упреждающих социально-экономическое бытие людей, характерно как для вероучения Иисуса Христа, который послал своих апостолов и учеников проповедовать веру в Единого Бога языческим народам всего мира, так и для вероучения, которое было передано Единым Богом (по-арабски - Аллахом) через Мухаммада язычникам-арабам, а также тем человеческим общностям, которые все еще пребывали в язычестве во времена ниспослания Корана [3].

Поэтому отнюдь не случайно Тору иначе называют Законом Моисея (или просто Законом). Здесь уместно напомнить также слова Иисуса Христа, который четко сказал последователям своего вероучения: «Не думайте, что Я пришел нарушить закон или пророков: не нарушить пришел Я, но исполнить» [1].

Затем и Мухаммаду было поручено передать, что Коран является судебником, по которому надлежит жить всем тем, кто принял единобожие по его вероуставу, то есть по шариату (правовой системе, изложенной в Коране): «И так Мы ниспослали его как арабский судебник» [3]. Не секрет, что примерно десятая часть Корана (около 500 аятов сур 2, 4 и 5) дают предписания как по религиозным, так по гражданским и уголовным делам. В полном согласии с Кораном, не отклоняясь от его принципиальных установок, существует и другой источник права мусульман - хадисы, то есть сведения о поступках и высказываниях пророка Мухаммада и его сподвижников.

Переживаемый ныне период ментального развития человечества мы условно называем цивилизацией научного мировосприятия, поскольку основой организации жизни подавляющего большинства наших современников являются не мировосприятие, а также нормы и правила, изложенные в священных писаниях единобожия или священных преданиях язычников, а результаты их нормотворческой деятельности, основанной на достижениях собственного интеллекта и познавательной деятельности.
Интеллектуальная деятельность современного человека охватывает практически все сферы его жизни начиная от законотворчества и заканчивая технологическими и прочими сферами, включая духовную сферу, связанную с культурой и искусством [8; 9].

Принципиальным отличием нынешней ментальной цивилизации является то, что она требует толерантного отношения не только к религиозным воззрениям людей, что закреплено практически во всех конституциях так называемых светских государств, но и к исторически сложившимся культурам этносов и народов, их самобытности, расовому своеобразию и языкам, ибо научное мировосприятие, в отличие от религиозного, не только не признает истин в последней инстанции, ориентируясь на бесконечность окружающего мира и познавательной деятельности самого человека, но и лояльно относится к таким формам и способам постижения и достижения истины, как диспут, дискуссия. Научная ментальность допускает существование альтернативных мнений, позиций и точек зрения, тогда как религиозная утверждает правильность сугубо одного мировосприятия, все остальные считая ересью, подлежащей безоговорочному искоренению из сознания людей [8; 9].

Начало последней ментальной цивилизации положила эпоха Возрождения (XIVXV вв.), а окончательное закрепление она получила в эпоху Просвещения (XVI-XIXвв.), когда в борьбе против так называемого феодально-сословного угнетения и духовной диктатуры церкви этносы и народы Европы (Англии, Франции, Италии и других государств) благодаря своей активной познавательной деятельности отошли от церковных догм о сотворении мира и людей и перешли к формированию собственных воззрений на окружающий мир и сущностную природу человека. Интеллектуальные возможности, способности и волевые качества человека стали мерилом его ценности для общества и определяли его место в социальной иерархии. Во главу угла был поставлен сам человек, его способности и возможности, а следом его права и обязанности [8; 9]. Причем сущностная природа человека в эпоху Просвещения многими мыслителями того времени (Дж. Локк, Р. Декарт, Ж.-Ж. Руссо и др.) рассматривалась не только как данная Богом, но и как результат собственных интеллектуальных усилий человека, его воли и деятельности. 
Широко известно, что к середине XVIII в. усилия таких великих просвещенцев, как Д. Дидро, Вольтер, О. Конт, И. Кант и др., в конечном итоге привели к появлению Декларации прав человека и гражданина (1789 г.), а затем и первой Конституции Франции (1795 г.), что ознаменовало полный отрыв от религиозного мировосприятия и законодательства, переданного через священные писания, и переход к так называемому светскому праву [8; 9].

\section{Результаты}

Результаты нашего исследования более чем убедительно показывают, что отношение представителей иных ментальных цивилизаций к тем явлениям, которые в современном мире квалифицируются в качестве уголовно наказуемых деяний, связанных, в частности, с экстремизмом и терроризмом, заметно отличается от нашего. В ментальные эпохи язычества и единобожия они рассматривались как проявление доблести, храбрости, самоотверженности, верности своему народу и беззаветной преданности Богу (богам).

Для подтверждения нашего мнения обратимся к историческим фактам, относящимся к эпохам язычества, монотеизма и научного мировосприятия. В сохранившихся текстах древнегреческих авторов явления экстремизма и терроризма составляют существенную часть жизни не только людей, но и великого множества богов, которым поклонялись и которых почитали.

При этом ни экстремизм людей и их богов, ни их откровенный террор по отношению к иноплеменникам и их богам не вызывал у язычников ни нареканий, ни порицаний, ни осуждений. Напротив, все эти явления воспринимались в качестве обязательного атрибута жизни, без которого невозможно обеспечить благополучие своей семьи, своего рода и своего племени.

Проиллюстрируем сказанное на примере одного из древнегреческих мифов, который связан с верховным божеством Эллады Зевсом. Арес, сын громовержца Зевса и богини брака Геры, являясь богом войны, получает наслаждение от яростных битв с обилием крови. Арес с громадным щитом носится среди грохота оружия, воплей воинов и стонов раненых. За ним следуют его сыновья Деймос (ужас) и Фобос (страх). Рядом с ними постоянно находится богиня раздора Эрида и богиня убийства Энюо. На груду мертвых тел Арес смотрит с нескрываемым ликованием [6].

Весьма определенное отношение к насилию и запугиванию противника в полисах (городах) Древней Греции и Древнего Рима демонстрирует исследование известного историка Фюстеля Де Куланжа. Основываясь на многочисленных исторических документах, Куланж в книге «Древний город. Религия, законы, институты Греции и Рима» пишет, что каждый из воинов, вступавших в сражение, был абсолютно уверен, что битву ведет не столько он, сколько его «родные боги» с богами противников. Воин взывал к своим богам: «О боги, посейте ужас и зло среди наших врагов. Лишите их и всех, кто населяет их земли и города, солнечного света. Пусть их города, их поля, их головы будут отданы вам» [5, с. 203].

Поэтому не случайно то, что по отношению к иноплеменникам у язычников не существовало никаких моральных ограничений и преград. Иноплеменник не мог рассчитывать на пощаду, милосердие и справедливость. Эти понятия существовали сугубо для соплеменников. Пленников-чужеземцев можно было убивать, а раненых надлежало добивать. Консул Марций публично хвастался, что обманул царя Македонии. Эмилий Павел продал в рабство сто тысяч жителей Эпира, добровольно сдавшихся в плен. Лакедомонянин Фебид захватил крепость в Фивах после того, как был заключен мир. Агесилая спросили о справедливости поступка Фебида, на что царь ответил: «Всякое действие, полезное для нашего отечества, правильно» [5, с. 207].

Приведем и другой пример. После победы над жителями Митилены афиняне решили истребить всех митиленцев. Они бы и уничтожили всех без исключения, если бы на следующий день не изменили ранее принятого решения. Они казнили только тысячу жителей и конфисковали все их земли. А после покорения Платей, умертвив всех мужчин, они продали в рабство женщин и детей. Ф. Куланж пишет: «Война велась не только против воинов, она велась против всего народа - мужчин, женщин, детей, рабов. Войну вели не только с людьми, но с полями и посевами. Сжигали поля, вырубали деревья; урожай врага почти всегда посвящался подземным богам, а потому сжигался» [5, c. 208].

Более того, скот и даже посевы врагов безжалостно уничтожались именно во имя 
своих родных богов, которым все это приносилось в жертву, ибо, по поверьям язычников, только родные боги-предки были способны обеспечить благополучие своих потомков на земле.

Война стирала с земли целые поселения. Территория вокруг Рима превратилась в безлюдное пространство. Было уничтожено, в частности, пятьдесят три города Лация и двадцать три города вольсков. На их месте со временем образовалось Понтийское болото [5].

Общеизвестно, что начало христианского периода в истории Римской империи также было ознаменовано жесточайшими гонениями на христиан со стороны римлян-язычников. По приказу властей христиан выискивали и убивали не только воины Рима, но и простые горожане. Так, по распоряжению Марка Аврелия христиан, не отрекшихся от своей веры, не только массово казнили, но и кидали на растерзание диким зверям, откровенно потешаясь [11].

На другом континенте язычники-индейцы в значительно более позднее историческое время (через полторы тысячи лет после описанных событий в Римской империи) имели ту же ментальность, что и их древнеримские языческие собратья.

Так, в работе известного исследователя жизни и быта индейцев Северной Америки Джона Мэнчипа Уайта «Индейцы Северной Америки. Быт, религия, культура» приводится множество примеров откровенно экстремистской и террористической, с точки зрения современных людей, деятельности индейцев в XVIIв. [13].

Стремление к господству над другими племенами составляло морально-нравственную основу индейцев. Например, племена ирокезов и чироков в кровавых битвах пытались подчинить родственные им племена гуронов, которых они практически полностью уничтожили. Ирокезы и чироки не оставили в живых ни одного индейца на берегах озера Гурон. Они же почти полностью уничтожили племена делаваров, нантикоков, шауни и шушанков, которые были расселены в районе озера Эри [13].

Что касается цивилизационной ментальности монотеистов, то есть иудеев, христиан и магометан (мусульман), то среди ранних письменно зафиксированных террористических организаций можно назвать секту сикариев (кинжальщиков), которая существовала в Иудее в I в. [2].
Члены секты терроризировали представителей еврейской знати, которые выступали за мир с римлянами. Они обвиняли их в отступничестве от заветов всесильного Бога Израиля и предательстве интересов народа. Полностью посвятив себя служению Единому Богу, они, становясь на путь мученичества, считали, что после свержения римлян всесильный Бог явится своему народу и избавит его от мук и страданий, идущих от Рима. Естественно, что сикарии воспринимались народом Израиля в качестве истинных защитников веры и родного народа. Они вызывали восхищение и почитание [2].

Ярчайшим примером отношения монотеистов-христиан к лицам, которых они считали еретиками, является деятельность средневековой испанской инквизиции.

Общеизвестно, что за период с 1481 по 1498 г. на кострах испанской инквизиции было загублено почти 10 тыс. чел., 6,5 тыс. были сожжены после казни через удушение, еще около 100 тыс. подверглись конфискации имущества, церковным наказаниям и сосланы на каторжные работы [4].

Не менее широко известны кровавые деяния испанского герцога Альбы, который был назначен наместником Испании в Нидерландах (1567-1573 гг.). Альба прибыл в Нидерланды с инструкцией от короля Филиппа II поддерживать истинную католическую веру во всей ее строгости, для чего решено было арестовать и казнить самых уважаемых граждан страны, подвергнув конфискации в пользу Испании все их имущество [4].

В течение трех месяцев герцог Альба послал на эшафот до 1800 знатнейших граждан Нидерландов. Малейшее подозрение и даже откровенная клевета служили основанием для вынесения смертного приговора и конфискации. Народ надо было держать в постоянном страхе и беспрекословном повиновении, и здесь решающим фактором служили религиозные (католические) воззрения короля Испании, возомнившего себя истинным блюстителем церковных устоев [4].

16 февраля 1568 г. произошло исключительное в мировой истории событие: все трехмиллионное население Нидерландов было приговорено королем Филиппом II к смертной казни из-за богоотступничества. Суд инквизиции единогласно принял предложение короля. Герцог Альба составил список из первых 800 почетных граждан 
Нидерландов, которые должны были быть казнены, повешены и сожжены сразу после Страстной недели. Приговор привели в исполнение. Мужчин сжигали на кострах, полыхавших по всей стране, а женщин хоронили заживо [4].

Не будем останавливаться на многочисленных фактах экстремизма и явного террора, имевших место в Средние века и в таких ныне просвещенных странах, как Франция, Англия и Германия. Они известны и в комментариях не нуждаются.

Не стали исключением и деяния опричнины в царствование крайне набожного Ивана Грозного, при котором была выстроена система розыска, дознания и казни, опиравшаяся на намеренное причинение страданий обвиняемым. К примеру, одним из распространенных методов получения сведений о совершенном преступлении был такое невыносимо тяжелое наказание, как «роспрос под дыбой».

Страшнейшие истязания рассматривались, во-первых, как эффективный способ получения признания, во-вторых, как вид тяжкого телесного наказания за преступления, но они никогда не считались преступным деяниям, подлежащим осуждению со стороны общества. Воля Всевышнего, обитающего на небесах, и его помазанника, властвующего на земле (пусть и в пределах одного государства), была священной и не подлежащей сомнению.

Среди террористических организаций, связанных с магометанским (мусульманским) вероисповеданием, можно назвать хашашаинов, которые в начале XI в. значительно развили искусство тайной войны и расширили диверсионную практику и применение насильственных средств достижения цели [10].

Так, около 1090 г. духовный лидер хашашаинов Хасан ибн Саббах захватил к северу от Хамадана крепость Аламут (современный Иран). В течение почти полутора столетий последовали Хасана ибн Саббаха терроризировали все правящие династии на территории от Персидского залива до Средиземного моря. Они уничтожили сотни халифов, султанов и военачальников, безжалостно убивали представителей исламского духовенства, которые, по их мнению, отступили от заветов и воли Всевышнего [10].

Если до начала эпох Возрождения, Просвещения и Реформации экстремизм и терроризм напрямую связывались с рели- гиозными воззрениями этносов и народов, а также отдельных групп людей (еретиков, сектантов и пр.), то с возникновением ментальной цивилизации научного мировосприятия они стали приобретать ярко выраженный политический, социальный, языковой, расовый и прочий, так называемый светский, характер.

Исторические факты более чем ясно свидетельствуют о том, что практически все войны до перехода народов на ментальную ступень научного мировосприятия были, как правило, религиозными. Иначе и быть не могло: религиозное мировосприятие, а также обусловленные им нормы и правила поведения охватывали и пронизывали все сферы жизни людей [15; 16].

Массовый уже отнюдь не религиозный, а сугубо политический террор был напрямую связан с событиями Великой французской революции (1789-1795 гг.). Робеспьер, бывший главным ее идеологом, сделал терроризм государственной политикой, направленной на уничтожение аристократии как класса. Неслучайно термин «террор» в современном значении стал употребляться лишь с конца XVIII в., то есть со времен Великой французской революции. Прочно он вошел в политический обиход в 1848 г. для названия действий революционеров-республиканцев и националистов в Италии и Испании, а следом получил распространение и в других странах мира [8].

Вспомним, что многочисленные покушения на жизнь ведущих политиков Европы и Америки сугубо на политической почве совершались в XIX и XX вв. Напомним лишь общеизвестные факты убийства американских президентов Маккинли и Гарфилда. В этом же ряду чисто политических стоит убийство в 1894 г. президента Франции Карно. В 1897 г. был убит премьер-министр Испании Антонио Кановаса, в 1898 г. - австро-венгерская императрица Элизабет, в 1900 г. король Италии Умберто.

Список убийств, не связанных с религиозными воззрениями террористов, можно продолжить, однако мы бы хотели здесь привести мнение известного политолога и социолога Самуэля Хантингтона о том, что если после Вестфальского мира (1648г.) и до начала Первой мировой войны в западном мире конфликты между государствами, точнее между правителями государств, как правило, разворачивались за новые территории и усиление экономической мощи 
своих стран, то все современные и будущие конфликты будут носить идеологический характер [14]. В целом соглашаясь с позицией С. Хантингтона, возразим ему лишь в том, что борьба будет вестись между западными и восточными цивилизациями. По нашему глубокому убеждению, борьба ранее, как и сегодня, разворачивалась и разворачивается внутри самих стран в связи с их переходом от одной цивилизационной ментальности к другой. В истории нашего государства этот тяжелейший слом на начальной стадии перехода от язычества к единобожию ярко запечатлен в выражении «Путята крестил Русь мечом, а Добрыня огнем».

Сегодня переход от религиозной ментальности к научному мировосприятию с соответствующей ей жизнедеятельностью протекает с характерными для переходных периодов трудностями у этносов и народов Юго-Восточной Азии. Общемировой же характер эта борьба (с вооруженными конфликтами и терактами) в наши дни приобрела лишь в связи с невиданными ранее интеграционными и миграционными процессами, обусловленными, с нашей точки зрения, демографическими взрывами XX и XXI вв. Сегодня на Земле уже проживает около восьми миллиардов человек, которые все больше начинают осознавать себя единым организмом, принципиально отличающимся от всего остального живого мира нашей планеты.

Если до начала XX в. переход от одной ментальной цивилизации к другой, как правило, протекал в рамках отдельных государств, не приобретая международного, а тем более планетарного масштаба, то с его наступлением имеет место так называемая глобализация. Не будем забывать, что становление самого международного права приходится именно на середину $\mathrm{XX}$ в., когда в 1945 г. была создана Организация Объединенных Наций, членами которой в настоящее время являются 193 государства мира.

Ярчайшим примером глобализации внутригосударственного цивилизационного конфликта можно считать процессы, протекающие в современной Сирии, где религиозные радикалы и фундаменталисты выступили против законно избранной власти в лице Б. Асада, а страны, имеющие в Сирии свои геополитические, экономические и прочие интересы, вмешались во внутренние дела республики.
Что касается России, то особенно ярко политический и социальный экстремизм и терроризм здесь проявились в деятельности многочисленных организаций русских революционеров-разночинцев в период с середины XIX до начала XX в., приведшей к Великой Октябрьской социалистической революции.

\section{Выводы}

Первый вывод заключается в том, что существующие ныне так называемые религиозные экстремисты и террористы разных мастей являются выразителями уходящих с исторической арены религиозного мировосприятия и соответствующего образа жизни. Религиозные экстремисты и террористы представляют позицию религиозных фанатиков, имеющую своим истоком религиозную ментальность соответствующего общества. При этом тот или иной этнос или народ, несмотря на принадлежность к религиозной ментальности, нельзя характеризовать как экстремистский. Ресоциализацию религиозных экстремистов и террористов необходимо проводить с учетом цивилизационной ментальности, с опорой прежде всего на толерантные возможности самих священных писаний, в частности Торы, Нового Завета и Корана. Хорошо известно, что Коран рассматривает названные писания в качестве трех посланий человечеству от Единого Бога. Осуществление указанной деятельности требует подготовки специальных кадров, причем из числа не только священнослужителей, но и сотрудников психологических и воспитательных служб УИС [15].

Второй вывод состоит в том, что в предстоящие годы на фоне закономерного угасания религиозного экстремизма и терроризма произойдет возрастание таких видов светского экстремизма и терроризма, как политический, социальный, расовый и языковой, то есть всех тех видов экстремизма, которые перечислены в ст. 278 и 282 УК РФ. Противодействие им требует прежде всего формирования высокого правосознания граждан страны, и здесь без системной и целенаправленной работы воспитательных и психологических служб УИС также не обойтись.

Допустимо ли восприятие экстремизма и терроризма в разные ментальные цивилизации рассматривать в качестве одного из важных способов формирования так на- 
зываемого политогенеза, а также правогенеза? Вне всякого сомнения. Подобный вывод, с нашей точки зрения, прямо вытекает из сравнения правового сознания этносов и народов, стоящих на разных уровнях ментального цивилизационного развития. А это в свою очередь дает основание государственным органам использовать обозна- ченные выше подходы к восприятию экстремизма и терроризма в разных ментальных цивилизациях для разработки теоретических и практических основ профилактики данных явлений, которые воспринимаются современным обществом в качестве крайне негативных, подлежащих уголовному преследованию и противодействию им.

\section{СПИСОК ЛИТЕРАТУРЫ}

1. Библия : книги священного писания Ветхого и Нового Завета (канонические) : в русском переводе с параллельными местами : перепечатано с Синодального издания. - Москва : Объединенные библейские общества, 1992. $292 \mathrm{c}$.

2. История терроризма. - URL: https://www.masu.edu.ru/antiterror/history (дата обращения: 12.02.2021).

3. Коран : перевод смыслов и комментарии Иман Валерии Пороховой / главный редактор Мухаммад Саид АльРошд. - 10-е изд., доп. - Москва : РИПОЛ классик, 2007. - 799 с. - ISBN 978-5-7905-4086-8.

4. Костры и пытки: как инквизиция вынесла смертный приговор всем жителям Нидерландов. - URL: https://www. vokrugsveta.ru/article/286617/ (дата обращения: 12.02.2021).

5. Куланж, Ф. Древний город: религия, законы, институты Греции и Рима / Фюстель де Куланж. - Москва : Центрполиграф, 2010. - 414 с. - ISBN 978-5-227-01968-4.

6. Мифы Древней Греции. - URL:https://grekomania.ru/ articles/mythology (дата обращения: 12.02.2021).

7. Настоящее значение философских афоризмов. - URL: https://Arzamasarzamas.academy/materials (дата обращения: 12.02.2021).

8. Оганесян, С. С. Мировоззренческое единство священных писаний единобожия - методологическая основа профилактики и противодействия религиозному экстремизму и терроризму / С. С. Оганесян, Н. В. Румянцев. - Москва : НИИИТ ФСИН России (Тверь), 2019. - 182 с. - ISBN 987-5-9632-0143-5.

9. Оганесян, С. С. Священные писания о неизбежности перехода от религиозного права к светскому / С. С. Оганесян // Представительная власть - XXI век: законодательство, комментарии, проблемы. - 2018. - № 1-2. - C. 30-34. 10. Первый миф об Ассасинах. - URL: https:// assassins23.wordpress.com/2013/05/28/первый-миф-об-ассасинах/ (дата обращения: 12.02.2021).

11. Свенцицкая, И. С. Первые христиане и Римская империя / Ирина Свенцицкая. - Москва : Вече, 2003. - 378 с. ISBN 5-7838-1307-9.

12. Тора (Пятикнижие Моисеево) / редактор русского перевода П. Гиль ; под общей редакцией Г. Брановера. - Москва : Арт-бизнесцентр : Шамир, 1993. - 1135 с. - ISBN 5-7287-0075-6.

13. Уайт, Д. М. Индейцы Северной Америки. Быт, религия, культура / Джон Мэнчип Уайт. - Москва : Центрполиграф, 2006. - 251 с. - ISBN 5-9524-2347-7. - URL: https://historylib.org/historybooks/Indeytsy-Severnoy-Ameriki--Byt-religiya--kultura-/ (дата обращения: 12.02.2021).

14. Хантингтон, С. Столкновение цивилизаций / Самюэль Хантингтон. - Москва : ACT, 2021. - 640 с. - ISBN $978-5-$ 17-096332-4

15. Dunn, R. S. The Age of Religious Wars, 1559-1689 / Richard S. Dunn. - New York : W. W. Norton \& Co., 1970. - 244 p.

16. Livet, G. Les guerres de religion (1559-1598) / Georges Livet. - Paris : Presses Universitaires de France, $1962 .-128$ p.

\section{REFERENCES}

1. Bibliya: knigi svyashchennogo pisaniya Vetkhogo i Novogo Zaveta (kanonicheskie): v russkom perevode s parallel'nymi mestami: perepechatano s Sinodal'nogo izdaniya [The Bible: the Books of Holy Scripture of the Old and New Testaments (canonical): in Russian translation with parallel places: reprinted from the Synodal edition]. Moscow: Ob"edinennye bibleiskie obshchestva, 1992. 292 p.

2. History of terrorism. Available at: https://www.masu.edu.ru/antiterror/history (accessed February 12, 2021). (In Russ.). 3. Koran: perevod smyslov i kommentarii Iman Valerii Porokhovoi / glavnyi redaktor Mukhammad Said Al'-Roshd [The Quran: translation of meanings and comments by Iman Valeria Porokhova. Editor-in-chief Muhammad Said Al-Roshd]. 10th edition, supplemented. Moscow: RIPOL klassik, 2007.799 p.

4. Fires and tortures: how the Inquisition passed the death sentence on all the inhabitants of the Netherlands. Available at: https://www.vokrugsveta.ru/article/286617/ (accessed: February 12, 2021). (In Russ.).

5. Coulanges F. Drevnii gorod: religiya, zakony, instituty Gretsii i Rima [The Ancient City: A Study on the Religion, Laws, and Institutions of Greece and Rome]. Moscow: Tsentrpoligraf, 2010. 414 p.

6. Myths of Ancient Greece. Available at: https://grekomania.ru/ articles/mythology (accessed: February 12, 2021). (In Russ.).

7. The real meaning of philosophical aphorisms. Available at:https://Arzamasarzamas.academy/materials (accessed: February 12, 2021). (In Russ.).

8. Oganesyan S.S., Rumyantsev N.V. Mirovozzrencheskoe edinstvo svyashchennykh pisanii edinobozhiya metodologicheskaya osnova profilaktiki i protivodeistviya religioznomu ekstremizmu i terrorizmu [Worldview unity of the holy scriptures of monotheism - a methodological basis for preventing and counteracting religious extremism and terrorism]. Moscow: NIIIT FSIN Rossii (Tver'), 2019. 182 p.

9. Oganesyan S.S. Holy scriptures on the inevitability of the transition from religious law to secular law. Predstavitel'naya vlast' - XXIvek: zakonodatel'stvo, kommentarii, problemy=Representative Power - 21st Century: Legislation, Commentary, Problems, 2018, no. 1-2, pp. 30-34. (In Russ.).

10. The first myth about the Assassins. Available at: https:// assassins23.wordpress.com/2013/05/28/pervyi-mif-obassasinakh/ (accessed: February 12, 2021). (In Russ.). 
11. Sventsitskaya I.S. Pervye khristiane i Rimskaya imperiya [First Christians and the Roman Empire]. Moscow: Veche, 2003. 378 p.

12. Tora (Pyatiknizhie Moiseevo) [Torah (The Five Books of Moses)]. Russian translation edited by P. Gil'; under the general editorship of G. Branover. Moscow: Art-biznestsentr: Shamir, 1993. 1135 p.

13. White J.M. Indeitsy Severnoi Ameriki. Byt, religiya, kul'tura [Everyday Life of the North American Indian]. Moscow: Tsentrpoligraf, 2006. 251 p. Available at: https://historylib.org/historybooks/Indeytsy-Severnoy-Ameriki--Byt--religiya-kultura-/ (accessed February 12, 2021).

14. Huntington S. Stolknovenie tsivilizatsii [The Clash of Civilizations]. Moscow: AST, 2021. 640 p.

15. Dunn R.S.The Age of Religious Wars, 1559-1689. New York: W. W. Norton \& Co., 1970. 244 p.

16. Livet G. Les guerres de religion (1559-1598). Paris: Presses Universitaires de France, 1962. 128 p.

\section{СВЕДЕНИЯ ОБ АВТОРАX / INFORMATION ABOUT THE AUTHORS}

СЕРГЕЙ САЯДОВИЧ ОГАНЕСЯН - ДОКТОР ПЕДаГОГИческих наук, профессор, государственный советник Российской Федерации 1 класса, главный научный сотрудник Научно-исследовательского института ФСИН России, г. Москва, Российская Федерация. ORCID: org/0000-0002-7257-7760, e-mail: ossduma@mail.ru ТАРИМ АНВЕРОВНА ХААДИ - СоИскатеЛЬ Ученой степени кандидата педагогических наук Института стратегии развития образования Российской академии образования, г. Москва, Российская Федерация, вицепрезидент фонда «Интеллект и Духовность». ORCID: https://orcid.org/0000-0003-3695-452X, e-mail: tarim. khadi@mail.ru
SERGEI S. OGANESYAN - Doctor of Sciences (Pedagogy), Professor, State Councilor of the Russian Federation, 1st class, Chief Researcher at theResearch Institute of FSIN Russia, Moscow, Russian Federation. ORCID: orcid.org/0000-0002-7257-7760, e-mail: ossduma@mail.ru

TARIM A. KHAADI - applicant for a Candidate of Sciences (Pedagogy) degree at the Institute for Strategy of Education Development of the Russian Academy of Education, Moscow, Russian Federation, vice-president of the Fund "Intellekt i dukhovnost'”. ORCID: https://orcid.org/00000003-3695-452X, e-mail: tarim.khadi@mail.ru 